Plants 2013, 2, 57-71; doi:10.3390/plants2010057

Article

www.mdpi.com/journal/plants

\title{
Antioxidant Activities and Anti-Cancer Cell Proliferation Properties of Natsuhaze (Vaccinium oldhamii Miq.), Shashanbo (V. bracteatum Thunb.) and Blueberry Cultivars
}

\author{
Hirotoshi Tsuda ${ }^{1}$, Hisato Kunitake ${ }^{2, *}$, Ryoko Kawasaki-Takaki ${ }^{2, \dagger}$, Kazuo Nishiyama ${ }^{2}$, \\ Masao Yamasaki ${ }^{2}$, Haruki Komatsu ${ }^{3}$ and Chizuko Yukizaki ${ }^{4}$ \\ 1 Interdisciplinary Graduate School of Agriculture and Engineering, University of Miyazaki, \\ Miyazaki 889-2192, Japan; E-Mail: vbracteatum@yahoo.co.jp (H.T.) \\ 2 Faculty of Agriculture, University of Miyazaki, Miyazaki 889-2192, Japan; \\ E-Mails: takaki-ryoko@pref.oita.lg.jp (R.K.-T.); nishiyam@cc.miyazaki-u.ac.jp (K.N.); \\ myamasaki@cc.miyazaki-u.ac.jp (M.Y.) \\ 3 School of Agriculture, Tokai University, Kumamoto 869-1404, Japan; \\ E-Mail: hkomatsu@agri.u-tokai.ac.jp (H.K.) \\ 4 Miyazaki Prefectural Food Research and Development Center, Miyazaki 880-0303, Japan; \\ E-Mail: yukizaki@iri.pref.miyazaki.jp (C.Y.)
}

$\uparrow$ Present address: Oita Prefectural Agriculture, Forestry and Fisheries Research Center Agricultural Research Division, Usa, Oita 872-0103, Japan.

* Author to whom correspondence should be addressed; E-Mail: hkuni@cc.miyazaki-u.ac.jp; Tel./Fax: +81-985-58-7166.

Received: 11 December 2012; in revised form: 20 January 2013 / Accepted: 6 February 2013 / Published: 15 February 2013

\begin{abstract}
Antioxidants are abundant in blueberries, and while there are many studies concerning the bioactive compound of fruit, it is only recently that the wild Vaccinium species has attracted attention for their diverse and abundant chemical components. The aim of this study was to investigate the bioactive compounds of blueberry cultivars and wild species found in Japan. Among the five extracts of the Vaccinium species, Natsuhaze
\end{abstract}


(Vaccinium oldhamii Miq.) was found to be the most effective at inhibiting the growth of HL-60 human leukemia cells in vitro. Although all ethanol extracts showed a growth inhibitory effect on HL-60 cells, the degree of the effects differed among the species. The extract of Natsuhaze induced apoptotic bodies and nucleosomal DNA fragmentation in the HL-60 cells. Of the extracts tested, that of Natsuhaze contained the largest amount of total polyphenols and showed the greatest antioxidant activity, but the anthocyanin content of Natsuhaze was similar to that of rabbiteye blueberry ( $V$. virgatum Ait.). The results showed that total polyphenols contributed to the high antioxidant activity and growth inhibitory effect on HL-60 human leukemia cells of Natsuhaze extract.

Keywords: anthocyanin; fruit; HL-60 human leukemia cells; polyphenol; Vaccinium corymbosum; V. virgatum

\section{Introduction}

There is strong evidence that the antioxidants present in fruits and vegetables protect lipids, proteins and nucleic acids against the oxidative damage initiated by free radicals [1], which play a major role in cancer, heart disease, and vascular and neurodegenerative diseases [2]. Antioxidants are abundantly present in blueberries (genus Vaccinium) [3], and numerous studies have been conducted on the bioactive compounds in blueberries and other fruits $[4,5]$. Although various types of antioxidants have been identified in fruits, anthocyanins and other polyphenols have received the greatest attention [6]. Epidemiological studies showed that some types of cancer are related to dietary habits and that people who consume large amounts of fruits and vegetables have a lower risk of cancer [7]. Fruits of berry species, including blueberries, strawberries, raspberries and cranberries, inhibit multiple stages of carcinogenesis and stimulate the apoptosis of cancer cells [8,9].

In Japan, 19 native species of the genus Vaccinium are distributed from Hokkaido in the north to the Kyushu region in the south [10]. The deciduous shrub Natsuhaze ( $V$. oldhamii Miq.) and the evergreen shrub Shashanbo ( $V$. bracteatum Thunb.) (Figure 1) grow naturally in a range from the east to the west of Japan. The edible Natsuhaze and Shashanbo berries are commonly harvested and processed for local foods [11,12]. While the pulp of blueberry cultivars is white, the pulp of Natsuhaze and Shashanbo is tinged with red. Anthocyanins are present in both the peel and pulp of bilberries (V. myltillus L.) but mainly in the peel of blueberries [13-15]. Therefore, the content of anthocyanins is clearly lower in blueberries than in bilberries on a flesh weight basis [14]. Furthermore, the antioxidant activity is mainly derived from the peel of the blueberry fruit [16], so it is important that anthocyanin and other phenol compounds accumulate in the pulp to raise antioxidant activities of whole fruits. Consequently, it is expected that high amount of anthocyanin with high antioxidant activity in the red 
pulp of Natsuhaze and Shashanbo. However, the functionality of these two wild Vaccinium species has been neither analyzed in detail, nor compared extensively with commercial cultivars of blueberry.

The objectives of the present study were as follows: (1) to determine the total anthocyanin content, total polyphenol content, and antioxidant activity of the fruit extracts of Natsuhaze, Shashanbo and blueberry cultivars; and, (2) to examine the effects of these extracts on the growth and apoptosis of the promyelocytic human leukemia cell line HL-60.

Figure 1. The fruits of Natsuhaze ( $V$. oldhamii Miq.) (A) and Shashanbo ( $V$. bracteatum Thunb.) (B). Bars indicate $10 \mathrm{~mm}$.
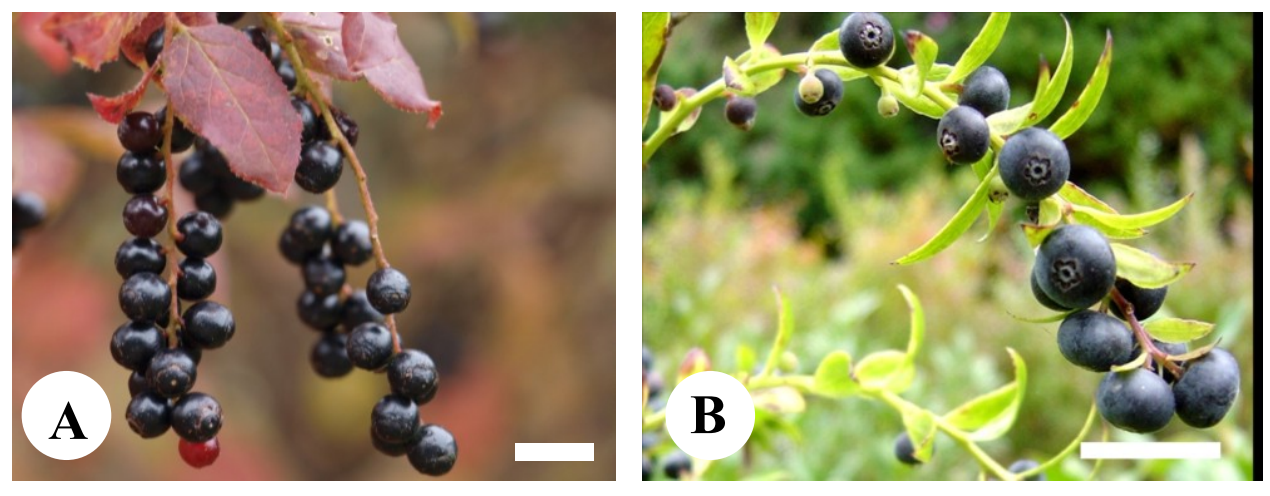

\section{Results}

\subsection{Anthocyanins}

We detected 14 anthocyanins in all berry extracts. Among the blueberry cultivars, rabbiteye blueberry had a consistently higher total anthocyanin content than the northern and southern highbush blueberries (Figure 2). Although "Homebell" had the highest total anthocyanin content in the fruits (26.5 mg cyanidin 3-glucoside equivalents $\cdot \mathrm{g}^{-1} \mathrm{DW}$ ) among the tested cultivars, it was not significantly different from Natsuhaze (19.1 mg cyanidin 3-glucoside equivalents $\left.\cdot \mathrm{g}^{-1} \mathrm{DW}\right)$, "Myers" (24.9 $\mathrm{mg}$ cyanidin 3-glucoside equivalents $\cdot \mathrm{g}^{-1} \mathrm{DW}$ ), and "Gardenblue" (20.7 $\mathrm{mg}$ cyanidin 3-glucoside equivalents $\left.\cdot \mathrm{g}^{-1} \mathrm{DW}\right)$. The anthocyanin profile of extract was also observed at the aglycon level. In northern highbush blueberries, delphinidin compounds constituted the principal anthocyanin, ranging from $39.6 \%$ ("Darrow") to $26.6 \%$ ("Duke"), compared to the total anthocyanin. In the southern highbush blueberries, delphinidin or malvidin compounds constituted the principal anthocyanin, ranging from $32.3 \%$ ("O'Neal" and "Sharpblue") to $19.5 \%$ ("Gerogeagem") and $27.8 \%$ ("Reveille") to $24.0 \%$ ("O'Neal"), respectively. In the rabbiteye blueberries, malvidin or delphinidin compounds also constituted the principal anthocyanin, ranging from $33.5 \%$ ("Homebell") to $26.2 \%$ ("Woodard") and $28.0 \%$ ("Woodard") to $18.0 \%$ ("Tifblue"), respectively. In the wild species, delphinidin compounds constituted the principal anthocyanin, ranging from 32.9\% (Shashanbo) to 26.6\% (Natsuhaze). Also, the relative content of malvidin was significant in Natsuhaze (20.3\%), but Shashanbo contained a large amount of cyanidin compound (31.5\%). 
Figure 2. Total anthocyanin content of fruits in blueberry cultivars and wild species.

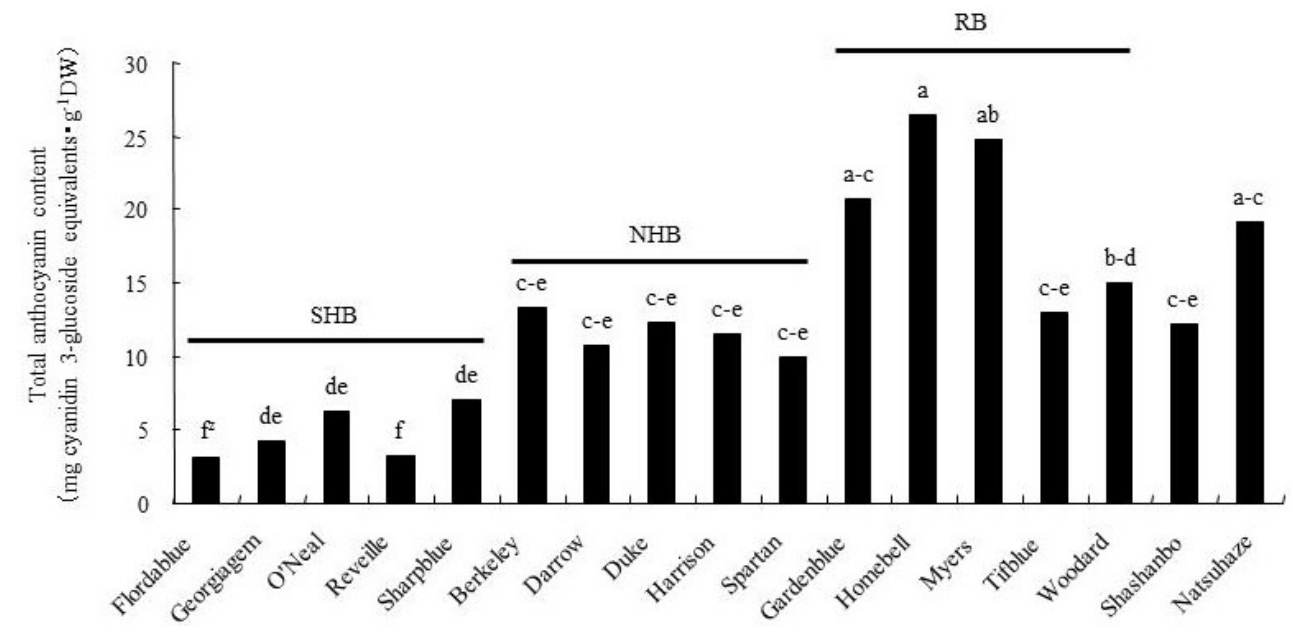

SHB: Southern highbush blueberry. NHB: Northern highbush blueberry. RB: Rabbiteye blueberry. Shashanbo (Vaccinium bracteatum Thunb.) and Natsuhaze (V. oldhamii Miq.). ${ }^{\mathrm{z}}$ Different letters represent significant differences in Tukey's multiple range test, $1 \%$ level.

\subsection{Total Polyphenol}

The total polyphenol contents of Natsuhaze $\left(65.5 \mathrm{mg}\right.$ gallic acid $\left.\cdot \mathrm{g}^{-1} \mathrm{DW}\right)$ and Shashanbo $(38.8 \mathrm{mg}$ gallic acid $\cdot \mathrm{g}^{-1} \mathrm{DW}$ ) were significantly higher than those of the blueberry cultivars (Figure 3 ). On the other hand, the analysis of the blueberry cultivars indicated that total polyphenol content in rabbiteye blueberry was higher than those of the southern and northern highbush blueberries. Among the blueberry cultivars, "Gardenblue" (35.1 mg gallic acid $\left.\cdot \mathrm{g}^{-1} \mathrm{DW}\right)$ was the highest and "Reveille" (12.0 $\mathrm{mg}$ gallic acid $\cdot \mathrm{g}^{-1} \mathrm{DW}$ ) was the lowest in total polyphenol content.

Figure 3. Total polyphenol content of fruits in blueberry cultivars and wild species.

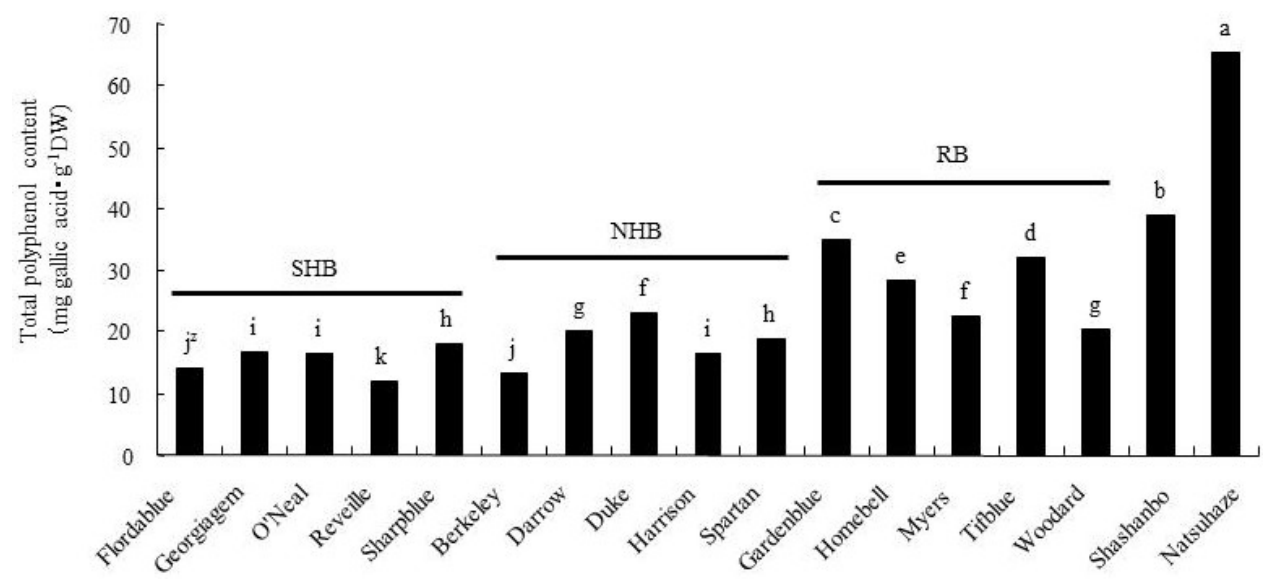

SHB: Southern highbush blueberry. NHB: Northern highbush blueberry. RB: Rabbiteye blueberry. Shashanbo (Vaccinium bracteatum Thunb.) and Natsuhaze (V. oldhamii Miq.). ${ }^{\mathrm{z}}$ Different letters represent significant differences in Tukey's multiple range test, $1 \%$ level. 


\subsection{Antioxidant Activity}

Among the three groups of blueberry cultivars, rabbiteye blueberry showed high antioxidant activity compared to the southern and northern highbush blueberries. Natsuhaze had the highest antioxidant activity in the ethanol extract among all the species analyzed. A large difference in antioxidant activities was observed among the species, ranging from 52.5 ("Reveille") to $456.2 \mu$ mol Trolox equivalents $\cdot \mathrm{g}^{-1} \mathrm{DW}$ (Natsuhaze) (Figure 4). This represents a $>8$-fold difference between the highest and lowest values.

Positive correlations were observed not only between antioxidant activity and total polyphenol content $\left(\mathrm{R}^{2}=0.9283,17\right.$ samples), but between antioxidant activity and the total anthocyanin content $\left(\mathrm{R}^{2}=0.3383,17\right.$ samples $)$.

Figure 4. Antioxidant activity of fruits in blueberry cultivars and wild species.

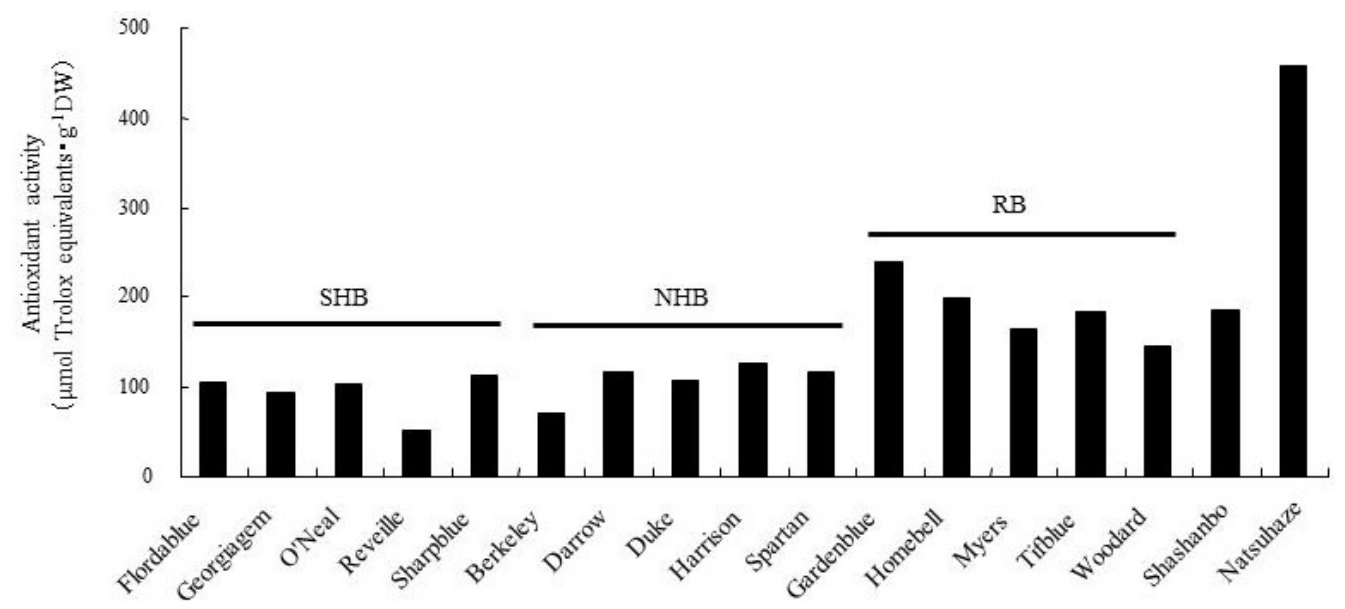

SHB: Southern highbush blueberry. NHB: Northern highbush blueberry. RB: Rabbiteye blueberry.

Shashanbo (Vaccinium bracteatum Thunb.) and Natsuhaze (V. oldhamii Miq.).

\subsection{Growth Inhibitory Effect of Fruit Extracts on HL-60 Cells}

Differences were observed among the species in their growth inhibitory effect of fruit extracts on HL-60 cells (Figure 5). Natsuhaze and Shashanbo showed significantly higher growth inhibitory effects than the blueberry cultivars, leading to the cell viability of $19.5 \%$ and $41.0 \%$, respectively at the same extract concentration $\left(0.5 \mathrm{mg} \cdot \mathrm{mL}^{-1}\right)$ (Figure 5). In contrast, blueberry cultivars did not show any significant effect on cell proliferation at the concentration $0.5 \mathrm{mg} \cdot \mathrm{mL}^{-1}$ fruit extract.

There was an inverse relationship between the antioxidant activity and cell viability $\left(R^{2}=0.5256\right.$, eight samples). That is to say, the extracts with the highest antioxidant activity inhibited HL-60 cell proliferation to the highest extent, giving the lowest proliferation levels. 
Figure 5. Effect of ethanol extracts on the viability of HL-60 cells.

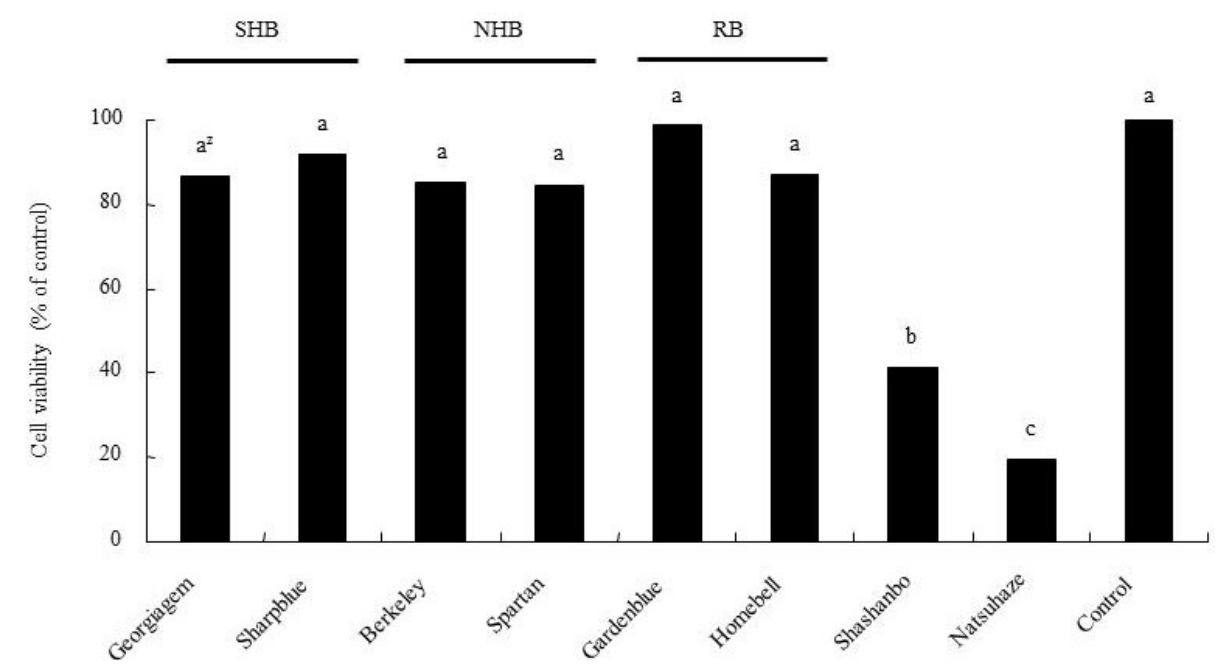

SHB: Southern highbush blueberry. NHB: Northern highbush blueberry. RB: Rabbiteye blueberry. Shashanbo (Vaccinium bracteatum Thunb.) and Natsuhaze (V. oldhamii Miq.). ${ }^{\mathrm{z}}$ Different letters represent significant differences in Tukey's multiple range test, $1 \%$ level.

\subsection{Effect of Fruit Extracts of Natsuhaze on Apoptosis-Induction of HL-60 Cells}

After the $6 \mathrm{~h}$ incubation of HL-60 cells with the extract of Natsuhaze at the concentration of $0.5 \mathrm{mg} \cdot \mathrm{mL}^{-1}$, apoptotic cell bodies were observed in the cells. The morphological changes of the ethanol extract-treated cells were observed by phase contrast microscopy (Figure 6A,B), and the nuclear condensation of the same cell population was also observed by fluorescence microscopy (Figure 6C,D). These results indicate that the ethanol extract-treated cells were suggesting apoptosis. In contrast, control cells did not show any sign of apoptosis.

In addition, the ethanol extract of Natsuhaze induced nucleosomal DNA fragmentation in HL-60 cells at $6 \mathrm{~h}$ of incubation (Figure 7). These results indicate that the ethanol extract of Natsuhaze induced apoptosis in HL-60 cells. Similarly, the nucleosomal DNA fragmentation was observed on agarose gel electrophoresis after treatment with Shashanbo ethanol extracts for $6 \mathrm{~h}$.

Figure 6. Effect of Natsuhaze ethanol extract on morphological change of HL-60 cells (A,B) and nuclei $(\mathbf{C}, \mathbf{D})$. (A,C) Control. (B,D) HL-60 cells treated with ethanol extract of Natsuhaze at $0.5 \mathrm{mg} \cdot \mathrm{mL}^{-1}$. Black arrows indicate the typical apoptotic cells, and white arrow indicates the nuclear condensation. Bars indicates $20 \mu \mathrm{m}(\mathbf{A}, \mathbf{B})$ and $0.5 \mu \mathrm{m}(\mathbf{C}, \mathbf{D})$, respectively.

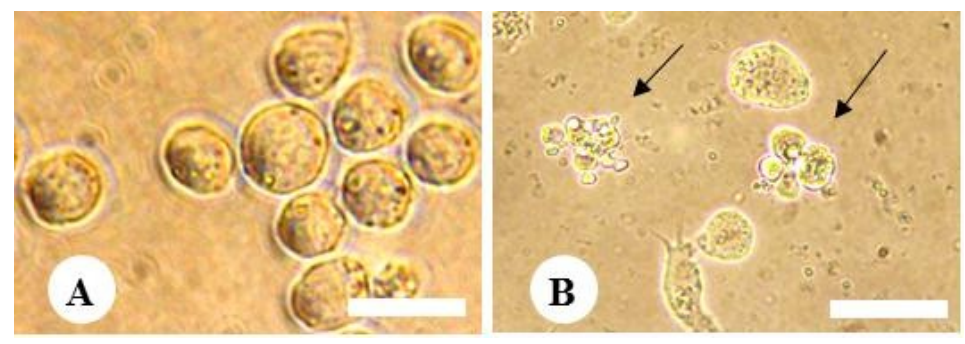


Figure 6. Cont.
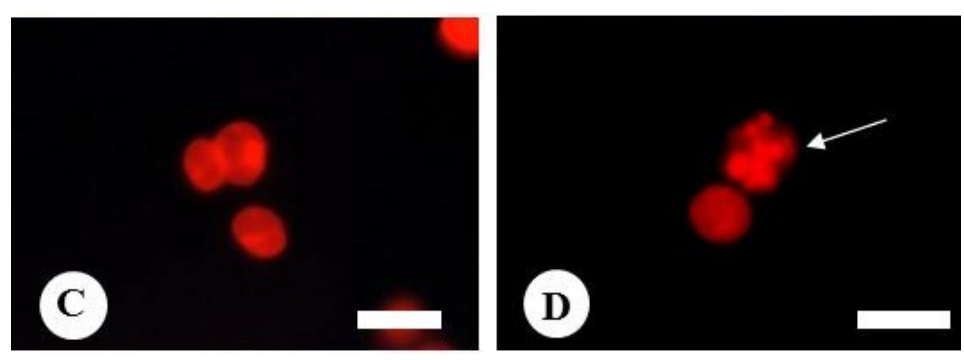

Figure 7. Analysis of DNA fragmentation patterns by agarose gel electrophoresis. DNA was extracted from HL-60 cells incubated with $0.5 \mathrm{mg} \cdot \mathrm{mL}^{-1}$ fruit ethanol extract for $6 \mathrm{~h}$. M: DNA marker, C: control, 1: Shashanbo (Vaccinium bracteatum Thunb.), 2: Natsuhaze (V. oldhamii Miq.).

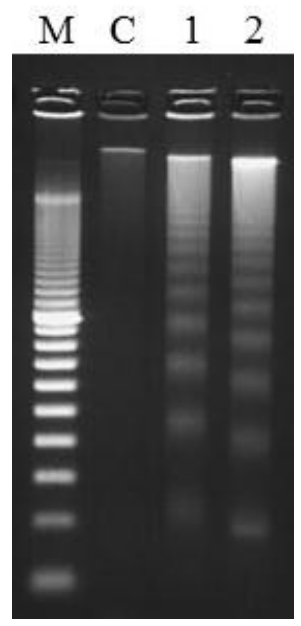

\section{Discussion}

The health benefits of fruits and vegetables combined in the human diet are well known and are strongly supported by scientific evidence [4]. Fruits and vegetables are also the largest contributors to antioxidant activity, which is considered a dietary quality indicator [17]. Although the antioxidant activity of food is derived from the accumulative and synergistic antioxidant power of vitamins, polyphenols, carotenoids and other minor constituents [18], polyphenols are the main antioxidants present in fruits and vegetables [19]. The production of free radicals in cells and body tissues has been linked to many of the diseases of aging [20-23]. Polyphenols acting as antioxidants may function as terminators of free radical chains [24]. Therefore, the consumption of fruits with high antioxidant activity can contribute to cancer prevention. Cell culture systems have been used to study the effects of fruit phytochemicals on cancer processes [25]. Consequently, in addition to our analysis of anthocyanin, total polyphenol content and antioxidant activity, we examined the inhibitory effect of fruit extracts on HL-60 cells, using an in vitro cell culture system. 
In the present study, the anthocyanin contents of Natsuhaze, Shashanbo, and rabbiteye blueberries were not significantly different. On the other hand, we found that the total polyphenol contents of Natsuhaze and Shashanbo were higher than those of the blueberry cultivars. Similar results were reported in another wild species of genus Vacciniium [26,27]. The high antioxidant activity of blueberries has been highly correlated to their anthocyanin and total polyphenol contents [26,28]. However, in our present experiment, the total polyphenol contents were strongly correlated with the antioxidant activity. Similar results have been reported by other researchers [27,29], who found a high correlation between antioxidant activity and total polyphenol content. Growth inhibitory effect of extracts in Natsuhaze and Shashanbo on HL-60 cells were significantly higher than those of the blueberry cultivars, and the Natsuhaze extract showed a strong inhibitory effect on the HL-60 cells via apoptosis. The bilberry extract and the anthocyanins, bearing delphinidin or malvidin as the aglycon, inhibit the growth of HL-60 cells through the induction of apoptosis [30]. In our experiments, $0.5 \mathrm{mg} \cdot \mathrm{mL}^{-1}$ Natsuhaze extracts significantly inhibited the growth of HL-60 cells at $24 \mathrm{~h}$ after being cultured, in contrast, the same concentration of bilberry extract did not significantly inhibit cell growth. Consequently, the growth inhibitory effect of HL-60 cells in Natsuhaze seemed to be higher than bilberry. However, the anthocyanin content of Natsuhaze was lower than rabbiteye blueberry, which was not effective for inhibition of HL-60 cells. Finally, it was thought that the substance which existed in the Natsuhaze extract and inhibited multiplication of HL-60 cells was not anthocyanine. Total polyphenol content of "Gardenblue", "Homebell", "Myers", "Tifblue", "Woodard" and "Duke" indicated 35.1, 28.5, 22.2, 32.2, 20.4 and $23.0 \mathrm{mg}$ gallic acid $\cdot \mathrm{g}^{-1} \mathrm{DW}$, respectively. These were higher than the value (12.8-18.8 $\mathrm{mg}$ gallic acid $\left.\cdot \mathrm{g}^{-1} \mathrm{DW}\right)$ reported by Wang et al. [16] in the same cultivars, which may be attributed to differences in environmental growing conditions. Kalt et al. [31] also indicated that synthesis of anthocyanin and other phenolic compounds can be influenced by various abiotic and biotic factors, including temperature, irradiation, herbivory, and pathogenic infection. In any event, the content of total polyphenol was 1.9 to 5.5-fold higher in Natsuhaze (65.6 mg gallic acid $\cdot \mathrm{g}^{-1} \mathrm{DW}$ ) than blueberry cultivars, which may be contributed to the high antioxidant activity and growth inhibitory effect on the HL-60 cells. The antioxidant activity, however, does not explain the high growth inhibitory effect of the Shashanbo extract on HL-60 cells. Other substances in Shashanbo might inhibit the viability of HL-60 cells, but the details are unclear. Generally, antioxidant activity of fruit extract tends to be related to total polyphenol in the fruits [6,32]. The main classes of flavonoids are flavanols (catechins and proanthocyanidins) and anthocyanin, and they contribute antioxidant activity [33-35]. The high antioxidant activities of lingonberry ( $V$. vitis-idaea L.), cranberry ( $V$. oxycoccus L.), and bog blueberry ( $V$. uliginosum L.) seem to be related to their high content of catechin or proanthocyanidins, compared to other berries [36-38]. Indeed, purified proanthocyanidins from lingonberry have been reported to have very high antioxidant activity in a range of assays [39]. Furthermore, the berry extracts from Vaccinim containing a considerable proportion of proanthocyanidins were evaluated for their ability to inhibit growth and stimulate apoptosis of human tumor cells in vitro $[9,40]$. In vitro studies employing breast tumor models treated with cranberry extract have 
reported dose-dependent induction of apoptosis coupled with cell cycle arrest [41]. Treatment of prostate tumor cells (LNCaP) with a wild blueberry proanthocyanidin fraction inhibited the growth of the cells. Moreover, two similar proanthocyanidin-rich fractions from cultivated blueberries significantly inhibited the growth of LNCaP cells [42]. Consequently, the phenolic compounds such as proanthocyanidins in the ethanol extract of Natsuhaze presumably inhibited the growth of HL-60 human leukemia cells through the induction of apoptosis.

\section{Experimental Section}

\subsection{Fruits}

We used two wild Vaccinium species, Natsuhaze ( $V$. oldhamii) and Shashanbo (V. bracteatum), and three types of blueberry cultivars: northern highbush blueberry ( $V$. corymbosum L.: "Berkeley", "Darrow", "Duke", "Harrison" and "Spartan"), southern highbush blueberry (V. corymbosum interspecific hybrid: "Flordablue", "Georgiagem", "O’Neal", "Reveille" and "Sharpblue"), and rabbiteye blueberry (V. virgatum Ait.: "Gardenblue", "Homebell", "Myers", "Tifblue" and "Woodard"). The fruits were harvested in the experimental field of the University of Miyazaki (blueberry cultivars) and at the private nursery in Fukuoka Prefecture (wild species). Each type of fruit was frozen and stored at $-30^{\circ} \mathrm{C}$ until used for experiments.

\subsection{Anthocyanins}

High-performance liquid chromatography (HPLC) was used to separate and determine individual anthocyanins in the blueberry tissue samples. Frozen berries were extracted with $100 \%(\mathrm{v} / \mathrm{v})$ methanol containing 1\% $\mathrm{HCl}$ using a homogenizer (DIAX100, Heidolph, Kelheim, Germany). The homogenized samples were evaporated to dryness, resolublized with pure water, and filled up to $10 \mathrm{~mL}$. These extracts were passed through a $0.22 \mu \mathrm{m}$ membrane filter (Millipore, Bedford, MA, USA) for HPLC analysis. Samples were analyzed by reversed-phase HPLC using a Shimadzu Prominence LC solution system (Shimadzu, Kyoto, Japan) with a STR ODS-column (Shimadzu, Kyoto, Japan). Chromatographic conditions were as follows: solvent A; $1 \%(\mathrm{v} / \mathrm{v})$ phosphoric acid; solvent $\mathrm{B} ; 1 \%(\mathrm{v} / \mathrm{v})$ phosphoric acid, $50 \%(\mathrm{v} / \mathrm{v})$ methanol and $0.1 \%(\mathrm{v} / \mathrm{v})$ trifluoroacetic acid; column temperature, $40{ }^{\circ} \mathrm{C}$; detection at $520 \mathrm{~nm}$; flow rate, $1.4 \mathrm{~mL} \cdot \mathrm{min}^{-1}$. The column was equilibrated with $40 \% \mathrm{~B}$ before use. The binary gradient was as follows: $40 \%-45 \% \mathrm{~B}(0-20 \mathrm{~min}), 45 \% \mathrm{~B}(20-35 \mathrm{~min}), 50 \% \mathrm{~B}(35-45 \mathrm{~min}), 50 \%-80 \%$ B (45-50 min), 80\% B (50-72 min), 40\% B (72-80 min). Retention times and spectra were compared with pure standards of malvidin 3-galactoside, peonidine 3-glucoside, cyanidin 3-glucoside, and malvidin 3-glucoside. Other putative anthocyanin peaks were presumed by the method of Ballington [43], and 15 anthocyanins were determined. The results are expressed as $\mathrm{mg}$ cyanidin 3-glucoside equivalents $\cdot \mathrm{g}^{-1} \mathrm{DW}$. The measurements of sample extracts were replicated three times. 


\subsection{Total Polyphenol}

Freeze-dried fruit powders $(0.1 \mathrm{~g})$ were dissolved in $80 \%(\mathrm{v} / \mathrm{v})$ methanol and passed through a $0.45 \mu \mathrm{m}$ membrane filter (Millipore, Bedford, MA, USA) for analysis. Total polyphenol contents were measured according to the Folin-Ciocalteu reagent method [44]. In brief, $3.2 \mathrm{~mL}$ of pure water, $200 \mu \mathrm{L}$ of each sample, $200 \mu \mathrm{L}$ of Folin-Ciocalteu's phenol reagent, and $400 \mu \mathrm{L}$ of saturated sodium carbonate solution were mixed. The absorbance was read at $760 \mathrm{~nm}$ after standing for $30 \mathrm{~min}$. Gallic acid dissolved in $80 \%$ (v/v) methanol was used as a standard. The total polyphenol contents are expressed as mg gallic acid equivalents $\cdot \mathrm{g}^{-1} \mathrm{DW}$. The measurements of sample extracts were replicated three times.

\subsection{Antioxidant Activity}

The antioxidant activity was determined by an 1,1-diphenyl-2-picrylhydrazyl (DPPH) free radical scavenging assay according to the method described by Suda [45]. In brief, $50 \mu \mathrm{L}$ of $20 \%$ ethanol solution and $50 \mu \mathrm{L}$ of a $200 \mathrm{mM}$ 2-morpholinoethanesulphonic acid (MES) buffer (pH 6.0) were added to $50 \mu \mathrm{L}$ of sample solution into a well of a 96 -well microplate. The sample solution was prepared by dilution of the fruit extract with $80 \%$ ethanol solution. The reaction was initiated by the addition of $50 \mu \mathrm{L}$ of $1.2 \mathrm{mM}$ DPPH in ethanol. After the reaction mixture had been allowed to stand for $20 \mathrm{~min}$ at ambient temperature, its absorbance at $520 \mathrm{~nm}$ was measured using an Immuno-Mini NJ-2300 microplate reader (Nalge Nunc International, Tokyo, Japan) with trolox (Aldrich Japan, Tokyo, Japan) as a standard. The antioxidant activity of these extracts is expressed as $\mu$ mol trolox equivalents $\cdot \mathrm{g}^{-1} \mathrm{DW}$. We investigated the correlations between antioxidant activity and the total anthocyanin content, or the total polyphenol content.

\subsection{Cells and Cell Culture}

The HL-60 cell line, human promyelocytic leukemia cells, was originally provided to us by Miyazaki Prefectural Industrial Support Foundation. HL-60 cells were cultured with RPMI-1640 medium supplemented with $10 \%$ fetal bovine serum containing 100 units $\cdot \mathrm{mL}^{-1}$ penicillin and $100 \mu \mathrm{g} \cdot \mathrm{mL}^{-1}$ streptomycin [46].

\subsection{Treatment of Cells with Fruit Extracts}

Freeze-dried fruit powders $(1.0 \mathrm{~g})$ were homogenized in $80 \%(\mathrm{v} / \mathrm{v})$ ethanol for $30 \mathrm{~s}$. The supernatants were filtered through No. 5 filter paper (ADVANTEC, Tokyo, Japan) and concentrated by rotary evaporation at $37^{\circ} \mathrm{C}$. The extracts were then lyophilized and tested as berry ethanol extracts. A suspension of HL-60 cells $\left(1.0 \times 10^{5}\right.$ cells $\left.\cdot \mathrm{mL}^{-1}\right)$ in the culture medium was mixed with ethanol extract and incubated for $24 \mathrm{~h}$. To compare the growth inhibitory effects of the ethanol extracts on the HL-60 cells among the blueberry cultivars and the wild species, the concentrations of these extracts were unified into $0.5 \mathrm{mg} \cdot \mathrm{mL}^{-1}$, whereby the concentration indicated the inhibitory effect on HL-60 
cells in the wild species based on the results of preliminary experiments. After incubation, cell viability was determined using a cell counting kit-8 (Dojindo, Kumamoto, Japan), which allowed extremely convenient assays with water-soluble tetrazolium salt, WST-8 (2-(2-methoxy- 4-nitrophenyl)-3-(4nitrophenyl)-5-(2,4-disulfophenyl)-2H-tetrazolium, monosodium salt) that produced a water-soluble formazan dye upon bioreduction in the presence of an electron carrier, 1-methoxy PMS (1-methoxy-5methylphenazinium methylsulfate). The amount of the formazan produced was directly proportional to the number of living cells. Absorption of the dye corresponding to the cell numbers was measured at $450 \mathrm{~nm}$ with the Immuno-Mini NJ-2300 microplate reader. The relative number of surviving cells was estimated in duplicate provided that the value of untreated cells was $100 \%$. The measurements of formazan as the effect of these extracts on the HL-60 calls were replicated five times, and we investigated the correlations between the antioxidant activities and the suppression of cell proliferation.

\subsection{Determination of Nuclear Morphology}

Cells were prepared as described above, and their morphological changes were observed with a phase-contrast microscope (CK40, Olympus, Tokyo, Japan). In the other experiments, morphological changes of nuclei with apoptosis were observed by staining with fluorescent dye. Briefly, the cells which were used in $24 \mathrm{~h}$ of the cell proliferation assay were recovered by centrifugal separation $(300 \times g$, 5 min). Frozen methanol $\left(-30^{\circ} \mathrm{C}\right)$ was added to the cells on a pellet after two washes with phosphate-buffered saline (PBS), and then the sample was allowed to stand at room temperature for $30 \mathrm{~min}$. Then, the cells obtained by centrifugation $(300 \times \mathrm{g}, 5 \mathrm{~min})$ were treated with PBS containing $10 \mu \mathrm{g} \cdot \mathrm{mL}^{-1}$ propidium iodide and $10 \mu \mathrm{g} \cdot \mathrm{mL}^{-1}$ RNase, then incubated at $37{ }^{\circ} \mathrm{C}$ for $30 \mathrm{~min}$. The morphological changes of nuclei were observed by fluorescence microscopy (BX51, Olympus).

\subsection{DNA Extraction and Agarose Gel Electrophoresis}

We evaluated the nucleosomal DNA fragmentation by agarose gel electrophoresis [46]. Briefly, cells were washed with ice-cold PBS and lysed with $10 \mathrm{mM}$ Tris- $\mathrm{HCl}$ (pH 7.4) containing $10 \mathrm{mM}$ EDTA and $0.5 \%(\mathrm{v} / \mathrm{v})$ Triton X-100. The cell lysate was treated with $100 \mu \mathrm{g} \cdot \mathrm{mL}^{-1}$ RNase A (Sigma-Aldrich, Steinhein, Germany) at $37{ }^{\circ} \mathrm{C}$ for $1 \mathrm{~h}$, followed by $100 \mu \mathrm{g} \cdot \mathrm{mL}^{-1}$ proteinase $\mathrm{K}$ (Sigma-Aldrich). Thereafter, DNA was precipitated in $0.5 \mathrm{M} \mathrm{NaCl}$ in $50 \%(\mathrm{v} / \mathrm{v})$ isopropanol and dissolved in Tris-EDTA buffer. The DNA samples were subjected to $2 \%(w / v)$ agarose gel electrophoresis, and the nucleosomal DNA fragmentation was detected after SYBR green dye staining.

\section{Conclusions}

Bioactive compounds of blueberry cultivars and wild species of Vaccinium in Japan were studied. Among $80 \%$ ethanol extracts of five Vaccinium species, Natsuhaze (Vaccinium oldhamii Miq.) was found to be the most effective at inhibiting the growth of HL-60 human leukemia cells in vitro. The ethanol extract of Natsuhaze induced apoptotic bodies and nucleosomal DNA fragmentation in the 
HL-60 cells. The fruit extracts of Natsuhaze contained the largest amount of total polyphenols and showed the greatest antioxidant activity. The flavonoid content and antioxidant activity of berry crops, including blueberries, are becoming targeted traits by berry breeders [5]. Although considerable variability has been observed in this characteristic, which is quantitatively inherited [47,48], specific breeding for this characteristic has not yet been undertaken [49]. In the present study, we found that Natsuhaze has high antioxidant activity and a growth inhibitory effect of HL-60 cells. Therefore, it could be a useful breeding material for a novel blueberry cultivar with high levels of bioactive compounds.

\section{Acknowledgments}

The authors are grateful to Masahiro Mii of Graduate School of Horticulture, Chiba University, for his advice and critical reading of this manuscript. This research was financially supported by the Sasakawa Scientific Research Grant from The Japan Science Society.

\section{References}

1. Retamales, J.B.; Hancock, J.F. Blueberries; CABI Publishing: Wallingford, UK, 2012.

2. Howard, L.R.; Clark, J.R.; Brownmiller, C. Antioxidant capacity and phenolic content in blueberries as affected by genotype and growing season. J. Sci. Food Agric. 2003, 83, 1238-1247.

3. Kalt, W.; Forney, C.F.; Martin, A.; Prior, R.L. Antioxidant capacity, vitamin C, phenolics, and anthocyanins after fresh storage of small fruits. J. Agric. Food Chem. 1999, 47, 4638-4644.

4. Hervert-Hernández, D.; García, J.L.; Rosado, J.L.; Goñi, I. The contribution of fruits and vegetables to dietary intake of polyphenols and antioxidant capacity in a Mexican rural diet: Importance of fruit and vegetable variety. Food Res. Int. 2011, 44, 1182-1189.

5. Wang, S.Y.; Chen, H.; Camp, M.J.; Ehlenfeldt, M.K. Flavonoid constituents and their contribution to antioxidant activity in cultivars and hybrids of rabbiteye blueberry (Vaccinium ashei Reade). Food Chem. 2012, 132, 855-864.

6. You, Q.; Wang, B.; Chen, F.; Huang, Z.; Wang, X.; Luo, P.G. Comparison of anthocyanins and phenolics in organically and conventionally grown blueberries in selected cultivars. Food Chem. 2011, 125, 201-208.

7. Steinmetz, K.A.; Potter, J.D. Vegetables, fruits and cancer. II. Mechanisms. Cancer Causes Control 1991, 2, 427-442.

8. Kraft, T.F.B.; Schmidt, B.M.; Yousef, G.G.; Knight, C.T.G.; Cuendet, M.; Kang, Y.H.; Pezzuto, J.M.; Seigler, D.S.; Lila, M.A. Chemopreventive potential of wild lowbush blueberry fruits in multiple stages of carcinogenesis. J. Food Sci. 2005, 70, 159-166.

9. Seeram, N.P.; Adams, L.S.; Zhang, Y.; Lee, R.; Sand, D.; Scheuller, H.S.; Heber, D. Blackberry, black raspberry, blueberry, cranberry, red raspberry, and strawberry extracts inhibit growth and stimulate apoptosis of human cancer cells in vitro. J. Agric. Food Chem. 2006, 54, 9329-9339. 
10. Yamazaki, T. Ericaceae. In Wild Flowers of JAPAN, Woody Plants (in Japanese); Satake, Y., Hara, H., Watari, S., Tominari, T., Eds.; Heibonsha: Tokyo, Japan, 1989; Volome 2, pp. 122-156.

11. Hirai, M.; Yoshimura, S.; Ohsako, T.; Kubo, N. Genetic diversity and phylogenetic relationships of the endangered species Vaccinium sieboldii and Vaccinium ciliatum (Ericaceae). Plant Syst. Evol. 2010, 287, 75-84.

12. Kunitake, H.; Tsuda, H.; Takagi, R.; Ohno, Y.; Kuroki, Y.; Yoshioka, K.; Kage, T.; Ito, T.; Komatsu, H. Possibility of wild blueberry shashanbo (Vaccinium bracteatum Thunb.) as a rootstock for cultivation of northern highbush blueberry in warm region (In Japanese with English abstract). Hortic. Res. (Japan) 2006, 5, 105-110.

13. Lee, J.; Wrolstad, R.E. Extraction of anthocyanins and polyphenolics from blueberry processing waste. J. Food Sci. 2004, 69, 564-573.

14. Riihinen, K.; Jaakola, L.; Karenlampi, S.; Hohtola, A. Organ-specific distribution of phenolic compounds in bilberry (Vaccinium myrtillus) and "northblue" blueberry (Vaccinium corymbosum $x$ V. angustifolium). Food Chem. 2008, 110, 156-160.

15. Ribera, A.E.; Reyes-Diaz, M.; Alberdi, M.; Zuñiga, G.E.; Mora, M.L. Antioxidant compounds in skin and pulp of fruits change among genotypes and maturity stages in highbush blueberry (Vaccinium corymbosum L.) growing in southern Chile. J. Soil. Sci. Plant Nutr. 2010, 10, 509-536.

16. Wang, S.Y.; Camp, M.J.; Ehlenfeldt, M.K. Antioxidant capacity and $\alpha$-glucosidase inhibitory activity in peel and flesh of blueberry (Vaccinium spp.) cultivars. Food Chem. 2012, 132, 1759-1768.

17. Saura-Calixto, F.; Goñi, I. Definition of the Mediterranean diet based on bioactive compounds. Crit. Rev. Food Sci. Nutr. 2009, 49, 145-152.

18. Liu, D.; Colina-Ibarra, J.; Kakuda, A.; Hue, S.J. The scavenging capacity and synergistic effects of lycopene, vitamin E, vitamin C and $\beta$-carotene mixtures on the DPPH free radical. LWT Food Sci. Technol. 2008, 41, 1344-1349.

19. Saura-Calixto, F.; Pérez-Jiménez, J.; Goñi, I. Dietary fiber and associated antioxidants in fruit and vegetables. In Fruit and Vegetable Phytochemicals; de La Rosa, L.A., Álvarez-Parilla, E., González-Aguilar, G.A., Eds.; Wiley: Ames, IA, USA, 2010; pp. 223-234.

20. Finkel, T.; Holbrook, N.J. Oxidants, oxidative stress and biology of ageing. Nature 2000, 408, 239-247.

21. Blomhoff, R.; Carlsen, M.H.; Andersen, L.F.; Jacobs, D.R. Health benefits of nuts: Potential role of antioxidants. Br. J. Nutr. 2006, 96, 52-60.

22. Gosslau, A.; Chen, K.Y. Nutraceuticals, apoptosis, and disease prevention. Nutrition 2004, 20, $95-102$.

23. Ghahremani-majd, H.; Dashti, F.; Dastan, D.; Mumivand, H.; Hadian, J.; Esna-Ashari, M. Antioxidant and Antimicrobial Activities of Iranian Mooseer (Allium hirtifolium Boiss) Populations. Hortic. Environ. Biotechnol. 2012, 53, 116-122.

24. Schroeter, H.; Boyd, C.; Spencer, J.P.E.; Williams, R.J.; Cadenas, E.; Rice-Evans, C. MAPK signaling in neurodegeneration: Influences of flavonoids and of nitric oxide. Neurobiol. Aging 2002, 23, 861-880. 
25. Prior, R.L.; Joseph, J. Berries and fruits in cancer chemoprevention. In Phytopharmaceuticals in Cancer Chemoprevention; Bagchi, D., Preuss, H.G., Eds.; CRC Press: Boca Raton, FL, USA, 2005; pp. 465-479.

26. Giovanelli, G.; Buratti, S. Comparison of polyphenolic composition and antioxidant activity of wild Italian blueberries and some cultivated varieties. Food Chem. 2009, 132, 855-864.

27. Koca, I.; Karadeniz, B. Antioxidant properties of blackberry and blueberry fruits grown in the Black Sea Region of Turkey. Sci. Hortic. 2009, 121, 447-450.

28. You, Q.; Wang, B; Chen, F.; Huang Z.; Wang, X.; Luo, P.G. Comparison of anthocyanins and phenolics in organically and conventionally grown blueberries in selected cultivars. Food Chem. 2011, 125, 201-208.

29. Wang, S.Y.; Chen, H.; Camp, M.J.; Ehlenfeldt, M.K. Flavonoid constituents and their contribution to antioxidant activity in cultivars and hybrids of rabbiteye blueberry (Vaccinium ashei Reade). Food Chem. 2012, 132, 855-864.

30. Katsube, N.; Iwashita, K.; Tsushida, T.; Yamaki, K.; Kobori, M. Induction of apoptosis in cancer cells by Bilberry (Vaccinium myrtillus) and the anthocyanins. J. Agric. Food Chem. 2003, 51, 68-75.

31. Kalt, W.; Ryan, D.A.J.; Duy, J.C.; Prior, R.L.; Ehlenfeldt, M.K.; vander Kloet, S.P. Interspecific variation in anthocyanins, phenolics, and antioxidant capacity among genotypes of highbush and lowbush blueberries (Vaccinium section Cyanococcus spp.). J. Agric. Food Chem. 2001, 49, 4761-4767.

32. Wu, X.; Beecher, G.R.; Holden, J.M.; Haytowitz, D.B.; Gebhardt, S.E.; Prior, R.L. Lipophilic and hydrophilic antioxidant capacities of common foods in the United States. J. Agric. Food Chem. 2004, 52, 4026-4037.

33. Gu, L.; Kelm, M.A.; Hammerstone, J.F.; Beecher, G.; Holden, J.; Haytowitz, D.; Gebhardt, S.; Prior, P.L. Concentrations of proanthocyanidins in common foods and estimations of normal consumption. J. Nutr. 2004, 134, 613-617.

34. Prior, R.L. Absorption and metabolism of anthocyanins: Potential health effects. In Phytochemicals: Mechanisms of Action; Meskin, M.S., Bidlack, W.R., Davies, A.J., Lewis, D.S., Randolph, R.K., Eds.; CRC Press: Boca Raton, FL, USA, 2003; pp. 1-16.

35. Scalbert, A.; Williamson, G. Dietary intake and bioavailability of polyphenols. J. Nutr. 2000, 130, 2073-2085.

36. Määttä-Riihinen, K.R.; Kamal-Eldin, A.; Mattila, P.H.; Gonzalez-Paramas, A.M.; Torronen, A.R. Distribution and contents of phenolic compounds in eighteen Scandinavian berry species. J. Agric. Food Chem. 2004, 52, 4477-4486.

37. Määttä-Riihinen, K.R.; Kahkonen, M.P.; Torronen, A.R.; Heinonen, I.M. Catechins and proanthocyanidins in berries of Vaccinium species and their antioxidant activity. J. Agric. Food Chem. 2005, 53, 8485-8491.

38. Zheng, W.; Wang, S.Y. Oxygen radical absorbing capacity of phenolics in blueberries, cranberries, chokeberries, and lingonberries. J. Agric. Food Chem. 2003, 51, 502-509. 
39. Ho, K.Y.; Tsai, C.C.; Huang, J.S.; Lin, T.C.; Hsu, Y.F.; Lin, C.C. Antioxidant activity of tannin compounds from Vaccinium vitis-idaea L. J. Pharm. Pharmacol. 1999, 51, 1075-1078.

40. Nandakumar, V.; Singh, T.; Katiyar, S. Multi-targeted prevention and therapy of cancer by proanthocyanidins. Cancer Lett. 2008, 269, 378-387.

41. Neto, C.C. Cranberry and blueberry: Evidence for protective effects against cancer and vascular diseases. Mol. Nutr. Food Res. 2007, 51, 652-664.

42. Schmidt, B.M.; Erdman, J.W., Jr.; Lila, M.A. Differential effects of blueberry proanthocyanidins on androgen sensitive and insensitive human prostate cancer cell lines. Cancer Lett. 2006, 231, 240-246.

43. Ballington, J.R.; Ballinger, W.E.; Maness, E.P. Interspecific differences in the percentage of anthocyanins, aglycone-sugars in the fruit of seven species of blueberries. J. Am. Soc. Hortic. Sci. 1987, 112, 859-864.

44. Singleton, U.L.; Rossi, J. Colorimetry of total phenolics with phosphomolybdic-posphotungustic acid reagent. Am. J. Enol. Vitic. 1965, 16, 144.

45. Suda, I. Determination of DPPH radical scavenging activity by spectrophotometry. In The Methods of Food Functions Analysis (In Japanese); Shinohara, K., Suzuki, T., Kaminogawa, S., Eds.; Korin: Tokyo, Japan, 2000; pp. 218-220.

46. Yamasaki, M.; Kawabe, A.; Nishimoto, K.; Madhyastha, H.; Sakakibara, Y.; Suiko, M.; Okamoto, T.; Suda, T.; Uehira, K.; Nishiyama, K. Dihydro-alpha-lipoic acid has more potent cytotoxicity than alpha-lipoic acid. In Vitro Cell Dev. Biol. Anim. 2009, 45, 275-280.

47. Connor, A.M.; Luby, J.J.; Tong, C.B.S. Variability in antioxidant activity in blueberry and correlations among different antioxidant assays. J. Am. Soc. Hortic. Sci. 2002, 127, 238-244.

48. Connor, A.M.; Luby, J.J.; Tong, C.B.S.; Finn, C.E.; Hancock, J.F. Genotypic and environmental variation in antioxidant activity, total phenolic content, and anthocyanin content among blueberry cultivars. J. Am. Soc. Hortic. Sci. 2002, 127, 89-97.

49. Rowland, L.J.; Hancock, J.F.; Bassil, N.V. Blueberry. In Genetics, Genomics and Breeding of Berries; Folta, K.M., Kole, C., Eds.; Science Publisher: Enfield, CT, USA, 2011; pp. 1-40.

(C) 2013 by the authors; licensee MDPI, Basel, Switzerland. This article is an open access article distributed under the terms and conditions of the Creative Commons Attribution license (http://creativecommons.org/licenses/by/3.0/). 